(c) $\underline{\text { www.ijrbat.in }}$

\title{
PERCEPTION OF FARMERS ABOUT AGRICULTURE, FOOD PRODUCTION AND CLIMATE CHANGE: A STUDY IN GOPALGANJ DISTRICT OF BIHAR
}

\author{
Habibullah Ansari ${ }^{1}$ \\ 1 Associate Professor and Head, Division of Social Psychology, A N Sinha Institute \\ of Social Studies, Patna-80001, Bihar, India. \\ Email: hbansari@yahoo.com
}

\begin{abstract}
:
Role of psychology in rural development is very important to understand the farmers' behaviours, perception, motivation, and crisis faced by them. The present study focussed on farmers' perceptions regarding food production, agriculture, climate change and other crises they face involving 36 farmers in Gopalganj District of Bihar in the year 2009 applying interviews, informal group discussions and observation methods. It came out that due to migration of younger generation, increased cost of production, the impact of climate change, the danger of floods and damaging of crops by forest animals farmers were giving up their cultivation. However, the farmers have attempted sharecropping (Bataee) system but the gross production on the same piece of land has gone down tremendously. Animal Husbandry, an alternative support, has also been reduced tremendously. In all such attempts, farmers are losing their battle and thus motivations and hope to do cultivations further and were craving to get some respite from the government.
\end{abstract}

Keywords: Farmer's perception, food crisis, agriculture, climate change, psychological crisis.

\section{INTRODUCTION:}

Study of the farming behavioural aspects of rural development is very important. It may encompass level of motivation, perception, stereotypes, prejudices, psychological crises, and family dynamics. Now, the farmers' behaviours in the present context are important as there is a very strong farmers' agitation going on against certain government legislations. They perceive that selling off their farm produces at minimum support price (MSP) is on stake and they have further perceived, such as above, that they are going to face several other problems in future. Farmers are the primary producers termed as 'Annadatta' but due to social- economic change, climate change, low level of productivity, high cost of production, the crisis of labour force compounded with the various natural disasters they are facing troubles and they may be no more future 'Annadata' if the crises continued. It is important to note that the increasing population in India requires more food, clothing and shelter for themselves and fuel and fodder for their livestock. Around $60-70 \%$ of the people in India are living in rural areas where they neither have adequate land holdings nor alternate employment to meet their basic needs. Among them, 35-40\% of families earning less than Rs.36000/- per annum are living in poverty. The 
poor are also adversely affected by the shortage of clean drinking water, poor health and illiteracy, leading to poor quality of life. Presently, about $25 \%$ of villagers do not have assured source of drinking water all-round the year (Hegde Narayan $\mathrm{G} ; 2010)$. In the absence of irrigation and modern technologies, it is difficult to attract the youth to engage themselves in agriculture. This has been the reason for increasing unemployment among rural youth, who are passing through tension and frustration (Hegde Narayan G; 2010). In addition, due to changing of perceptions and lifestyles of youth they are not engaging themselves in agriculture and are looking for employment somewhere else and thus they are migrating from rural to urban areas.

It has been seen the importance of farmers through the views of consumers that how important the farmers are for our food safety and protection of land and environment. It is evident that studies on farmers' perceptions on topics related to sustainable agriculture, agricultural regulations, food issues, and agricultural technologies were conducted in some of the world's largest agriculture countries including Brazil, China, France, Germany, India, Spain and the United States (Dales Joe, 2014) reveal that in regards to the role of the farmer, the farmers $(92.6 \%)$ and consumers $(90.9 \%)$ both highly agree all over the world that "farmers fulfil a necessary function in the society". Farmers are considered the main producers of food in all countries by both the consumers (88.6\%) and the farmers (92.9\%). In general, most consumers and farmers agree that farmers are the caretakers of the land; they are responsible for protecting and caring the land and the environment. In turn, the consumers also support and care about the farmers. Consumers across all countries claim that they 'understand the importance of farmers in securing the food supply' (global average agreement: 75\%) (Dales Joe, 2014).
Farmers are facing double burden; one side the cost of agriculture and another side adaptation with climate change. Climate change and changing local ecologies such as excessive heat and cold, drought and excessive rains in some areas etc. have added the problems to the farmers and thus they are facing tremendous problems in cultivation and finally leaving it and searching for some alternative forms of incomes. In such situation, their children are migrating to the urban centres in search of jobs. Their sufferings sprouting out of fear and anxiety and its tentacles root in the loss in agriculture, food production, repaying of debts etc., further leads to frustration, depression and suicides among them. In such a condition it is important to understand farmers' perceptions, understanding, and attitudes towards food production, agriculture, and animal husbandry to reflect on policy formulations and implementations.

\section{REVIEW OF LITERATURES}

There is a dearth of study by psychologists on the issues of perceptions of farmers regarding food production, climate change, animal husbandry etc. Few studies have been done by other disciplines. By some agricultural scientists have examined constraints perceived by farmers in the crop-dairy mixed farming system on small farms in Parbhani district of Marathwada region of Maharashtra state (Shrey Ravi et al, 2015) which finds major constraints were non-availability of inputs at the village level, high cost of inputs and lack of technical guidance in time reported by the high majority of the farmers. In case of local cow owner majority were facing the constraints of low productivity, marketing of local cow, crossbreed cow and of buffaloes. Another study by agriculture student has been done on assessing farmers "perception on the effectiveness of their extension agents in knowledge transfer to maize farmers in Kilindi District which reveals that majority of the farmers were impacted by plant diseases and 
pests, low market prices and low yields, respectively and they strongly disagreed on the effectiveness of Agricultural Extension Agents (AEAs) in knowledge transfer, 90.9\% to 99.2\% of respondents had negative perceptions on the advantages of AEAs (Mcharo, Anna Charles, 2013).

A study on farmers' perceptions on climate change and adaption in Bangladesh reveals that the perceptions of changes in the climate and of extreme climatic events are similar to actual climatic condition. They recognized the impacts on their livelihood and resources, resulting in an increased sense of vulnerability. To build resilience, households have undertaken a range of farming and non-farming adaptation strategies, which vary significantly among the farming community (Alam G.M et al, 2017). In one pilot study conducted in two villages in Uttarakhand reveals that all respondents had felt that rainfall had declined in quantity and an increase in intense rainfall which destroyed crops. They also observed a decline in groundwater with an increase in heat intensity (Kelkar et al. 2008). In another study on farmers' perceptions of climate change carried out in Kancheepuram, the northern coastal district of South India at the end of the South-West monsoon season in 2012 (Kharif cropping season in India) reveals that farmers have perceived climate variability and identified increasing temperature, delayed onset, intermittent dry spells and decreasing soil moisture as the critical factors affecting their cultivation. Some of them have started to adapt to these changes by cultivating and they have indicated their specific adaptation needs, a number of which could be incorporated into sitespecific adaption strategies and policies (Praveen Dhanya and Ramachandran Andimuthu, 2015). In a study conducted in a tribal region of Udaipur district of Rajasthan on 425 farmers to find out their perception towards agriculture technology which revealed that majority of the farmers had perceived knowledge regarding the use of various fertilizers and techniques of using line sowing and seed replacement technologies. A minority of farmers had possessed knowledge of the use of green manure and microelements, broadcasting, cultivation of fruits and vegetable crops and making compost/vermicompost. The majority of farmers perceived climatic changes, uneven distribution and uncertain of the rainfalls, declining level of groundwater on their farms and non-remunerative price of crops during last ten years (Meena G L and Punjabi N K, 2012).

In a study, using a qualitative approach looks into the perceived changes in rainfall and temperature, their impacts and adaptations strategies taken up by farmers in four villages in the states of Maharashtra and Andhra Pradesh. The farmers had increasingly noticed variability in climate over the past 5 years. Farmers felt that there had been an increase in temperature and the women confirmed it by expressing that it was getting difficult for them to work in the fields because of extreme heat and unprecedented cold temperatures. The farmers also perceived that there had been significant variations in the quantity and distribution of rainfall over the years. They believed that the rainfall was more intense, with fewer rainy days, and had an extremely erratic distribution (Banerjee, 2015).

In another study on farmers' perception on droughts and impacts in Maharashtra it was found that there was a decrease in the yield of cereals, horticultural crops, livestock production and loss of employment, all associated with decreased income of farmers, were the most immediate economic impacts of drought. Social impacts were also seen such as migration, impacts on health, schooling of children, hopelessness and sense of loss, conflicts in society for water, and malnutrition due to changing food preferences etc. Impacts on local environment were also observed 
such as increases in average atmospheric temperature, pasture-forest degradation, deteriorated water quality, damage to fish habitatwild life, and groundwater depletion was perceived by farmers to a high extent (Udmale Parmeshwar et al, 2014).

However, it was difficult to find studies on farmers' perception in psychology. Psychologists have hardly focussed on the issues of farmers' behaviours and rural development. So, this firsthand field visit report gives many clues for further study into this area.

\section{METHODS AND MATERIALS}

A simple method was used, as it was a field visit study and not a comprehensive study per se. An easy-going sample was used from various villages namely Indarwan main, Indarwan Abaidullah, Bakhraur Pachpatia, Chota Kalyanpur, Kalyanpur Mauja, Nadhana, Pet Biraicha, Gopalganj town, Devapur, Barauli Bazar, Bagahaan, Thawe, and Baluhi Bhainsahin of Gopalgnaj district of Bihar state, India. The informal group discussions and interviews were used on the 36 respondents comprising farmers, labourers and key informants such as Panchayat Mukhias, Sarpancha, villages level workers (VLWs), retired teachers, Pujaries and some local medical practitioners (in villages all are involved in farming) with an objective to find out their views about agriculture, food production and impact of climate change and an overall perception about the social and economic changes in rural areas related agriculture and livelihoods in the year 2009. Information was recorded using an audio recorder, pen and papers. A comprehensive verbatim was prepared and analysed and accordingly drawn the inferences.

\section{RESULTS AND DISCUSSIONS}

\section{Reduction in Food Production, Labour Force, and Bataee System (Sharecropping)}

It was found that due to the migration of rural workforce to the urban centres, the village farmers were facing a tremendous shortage of labour force to cultivate their lands. Even from the farmers' family, members have migrated to the urban areas in search of jobs; they themselves had insufficient in-house labour force for the cultivation of their own lands.

Those who were landed people and had no labour force, many of them had given their land on Bataee System (sharecropping) to the landless people - to those who had more hands. Due to the Bataee System, the gross production on the same piece of land had gone down tremendously. The Bataeedars (sharecroppers) were not much concerned about maintaining the fertility of the land as that land is only temporarily under them, and since at any time the original tenants could take it back, they did not put sufficient fertilizer and manure.

The farmers had reported that by cultivating on their own land they were able to get a sizeable quantity of production, whereas by leasing out their land on Bataee, they were getting only half of the gross production. Under the Bataee System, the gross production is divided into two and thus in actually, they get only 25 per cent of their original product. Therefore, the net grain they get under Bataee is only one-fourth or even less than what they were getting after cultivating by themselves.

Another reason for leaving the land uncultivated is the increased cost of production, i.e., irrigation water (Rs. 100 per hour through private bore wells using diesel engine pump sets), cost of seeds, fertilizers, pesticides, ploughing by tractors, etc. Many farmers, particularly those who have other sources of income as their sons and grandsons are in salaried jobs, or in business, or any other profession, and they are generally well-to-do households, they do not cultivate their entire land. Either they leave it uncultivated or give on Bataee. They prefer to purchase the food grains from the market rather than getting involved in cultivation. 
On the other hand, there are some farmers who are poor and they have no other income; they are compelled to work on their land. Once they calculate the total input on the cost of production and the actual production yield, they find themselves in a loss; however, they have no other way out but to continue cultivation. In the case of floods and droughts, these farmers suffer the most.

Rural-urban migration in search of jobs and cash income increased cost of production is the major reasons for diminishing agricultural works and food production in rural areas.

One big farmer, Shri Babulal Singh (Name changed) mentions, "It is too costly to cultivate all lands. I cultivate only as much as I require for meeting needs for home consumption." $\mathrm{He}$ expressed that he was facing a huge crisis of labour. Now even the poor people, because of the migration of their sons and having cash income, they do not want to work on wages. Even the younger generation is not willing to work in the villages." He further expresses, "Why should I take a lot of burden and pains of cultivating all the land I have." Shri Babulal Singh is a rich person and his all sons were living in towns and had high incomes.

So the landed farmers are giving up cultivation on their land and poor had no land to cultivate so the gross production on land is diminishing in rural areas.

Md Ismaeel haaq (name changed), a middle-level farmer, reported that those who were totally dependent on the agriculture for everything and had no other source of cash income as their sons are not in salaried jobs are bound to work on agriculture. They put all their hard labour, costly fertilizers, water for irrigation and tools - tractors, pump sets, threshers, etc., to get high production as that is the only source of livelihood for them. However, if they calculate the cost of each factor labour, water, fertilizers, tools, etc., it is found that it is in the negative, but they are khetihars (cultivators), they have to work during all the seasons whether they get the desired product or not - as cultivation is their dharma (righteous duty).

Due to the increased cost of production, the Bataeedars are not ready to take land for cultivation because there is a loss in cultivation on Bataee. After putting in all the hard labour and money into the fields, they have to share half of the products to the original tenants. Only a few labour class families who could not migrate to urban centres and they having no lands of their own, but sufficient manpower could do cultivation on Bataee.

To minimise the cost of production, they used to employ minimum labour, put minimum fertilizers and water, and used local seeds. In this way, the gross production on the same piece of land comes down and after two to three years the fertility and quality of land get deteriorated. Many farmers reported that nowadays no Bataeedars are prepared to take their lands on Bataee so they leave their land uncultivated. Regarding the reduction of land fertility, many villagers reported that this is because animal husbandry is reducing.

So many farmers are leaving their land uncultivated due to reduction in production losing land fertility by giving it on Bataee system.

Regarding the reduction of land fertility, many villagers reported that this is because animal husbandry is reducing. They do not put manure in their fields. Depending only on chemical fertilizers, the fertility and productivity of land is reducing year after year. They believe that an inadequate quantity of fertilizers is the main cause of the land becoming infertile, but due to heavy cost, they are not able to put the required dose of fertilizers.

The villagers showed their apathy towards government support for agriculture. They reported 
that in the earlier days a VLW was appointed by the government to educate the farmers about the techniques of agriculture, which is totally lost today. Some rich farmers were getting subsidized fertilizers and seeds through cooperative societies, but now they are get nothing.

They reported that not only the food grain production has gone down, but also the commercial crops (sugarcane and tobacco) had gone down. Few rich farmers of the area, such as Shri Babulal Singh and Dr Pratap Sharan Singh (Name changed), reported that due to the reduced production of sugarcane, they are being approached by the officers of the Sugar Mills to increase the production of sugarcane but they are not willing to do so because they are not getting any benefits of increased production.

On the other hand, the price of tobacco has gone much higher, but due to the erratic weather and thunderstorms, at the time when tobacco crops are ready for harvesting, the crops have been ruined and caused heavy losses to the farmers.

Another cause of the reduction in agricultural production in villages is the damage of crops caused by the untamed forest deer, which have come up to the villages in big hordes. Earlier this animal was not found in the area, but for the last 4-5 years their population has increased tremendously and they are damaging the readyto-reap crops like maize, wheat, vegetables, fruits, etc. Similar damages have been caused by monkeys. They damage the fruits of mangoes, guavas, even certain vegetables, maize, etc. The farmers are unable to protect their crops and there is no initiative taken by the government to prevent these animals and to protect their crops. Due to several reasons (particularly religious), the people cannot kill these animals, as reported by Shri Ramji Prasad (name changed), Babulal Singh and many others.

\section{Costly Irrigation and Useless Canals}

In Gopalganj District, the main source of irrigation water is private tube wells using diesel engine pump sets. Water is supplied at Rupees 80-100 per hour through these pump sets, which is very costly. Another source of irrigation was the electric motors installed by the government for operating the tube wells; but reportedly almost all the electric motors are dysfunctional because of improper maintenance, erratic supply of electricity, sometimes due to damage of the electric poles and wires, and negative responses of the government officials. The villagers reported that electric tube wells are the cheapest irrigation source for us if they become functional and electric supply could be regular. They said that the cost of one katha of land (roughly 100 sq. yards) irrigated by an electric tube well is Rupees 5 only, which is much cheaper than irrigating the same land by diesel pump set.

There are canals dug under the Gandak River Project. There are arteries of canals in the area but not suitable to supply water to lands when farmers need to irrigate their lands. Some of these are totally ruined, not used for water supply. Some of these canals are used to drain the floodwater when there is rain water everywhere. Sometimes canal water damages the crops because of the mismanagement of water. There is no proper channel to divert the water to the fields. Water is overflowing unnecessarily into the fields, which do not require water. In the surrounding lands to the canals are water-logged. Farmers reported that these canals are useless, rather harmful in many ways. If we are given subsidy on the diesel engine pump sets and on diesel prices, we would be able to manage our irrigation better. The water of the canals is not under our control. We cannot use it as per our requirements.

Some villagers reported that there are some canals but there has never been any water in them since they had been constructed. The government had taken our lands, constructed the canals, but we 
have never got water since they were constructed some 30-40 years ago. Due to the faulty construction by the engineers and irregular level surface, the water is not able to flow across the entire length of the canal; hence the water could not flow from the point of supply to the farthest end. As these canals could not be used for the desired purpose, i.e., irrigation, due to wear and tear they have become sloped; their beds filled with silt deposits, both sides have disappeared and are being used as roads. In some places, the entire canal has disappeared and only the bed of the canal has remained as small foot-roads. All the canal projects in the area are a colossal waste of cultivable land, government money on digging the canals, and on salaries to the employees; and most importantly, useless for the farmers.

Some big canals (called 'Bum Nahar'), which are the main distributors of water to their subsidiaries, are filled up with sand/silt and the flow of water is hindered. That is one of the reasons for water not reaching the small canals at distant ends.

Irrigation from ponds has not been reported in the area. Irrigation from rivers is possible only when there is water in them, but during the spring season, there is hardly any water in the rivers. Even if at all water could be supplied, it becomes costly because it is pumped through diesel engine pump sets. The traditional source of irrigation through wells has been abolished. Many wells are not in use and many are filled up. The cheapest source of drinking water is through hand pumps available to almost all villagers.

\section{Reducing Livestock/Animal Husbandry}

The villagers of Gopalganj District were asked the question as to why did they not keep cattle as they used to do some years/decades ago? They responded that keeping oxen, cows, buffaloes, etc., are a costly business now. One person from the family or a servant on a regular basis is required to take care of the cattle. Now because of the shortage of labour, and rural to urban migration, this is not possible.

Due to certain changes in the culture of rural lives, even their children of modern times are not willing to take up cattle-rearing as an occupation. As for the new educated generation, they are opposed to the idea of carrying on the old traditional arduous work of keeping cattle. If they keep animals, they have to clean the droppings (dung) of the animals, arrange for their fodder, and feed the animal three times, etc., which is against their standard now. Some villagers do not sell milk (it is only for their home consumption), thus they do not get any return income, but they have to bear the cost of resources for feeding the cattle, etc.

Now because of the availability of tractors, there is no use of oxen for ploughing the land, hence villagers preferred not to keep oxen. Few villagers keep cows or buffaloes.

\section{Impact of Climate Change}

As an impact of climate change and ecological crisis, many villagers have reported that a particular tree called shisham is on the verge of extinction. These trees are drying and decaying due to climate change or certain unknown disease. The area was full of shisham trees some ten years ago and that was the main source of fuel for cooking and furniture, making houses, huts, etc. Villagers think that due to the use of chemical fertilizers in the land over a long period of time, these trees are now dying out. Because of the nonsurvival of these trees, the people of the area are going to face a shortage of cooking fuel in every household, whether they are rich or poor. The government forest department has not taken any initiative to protect these trees. There is an urgent need to protect these trees, otherwise, nobody will have a piece of wood to cook or make furniture.

Another impact of climate change was reported on the pulse crops. A pulse plant called Arahar is becoming unproductive year after year. It does flower but does not produce seeds. Nobody knows 
why. People have stopped the cultivation of this pulse crop, causing a dearth of Arhar pulse. Other crops which are on the verge of extinction are cotton, Sawan, Kodo, Madua, China, Tanguni, Jowar, Bajra, etc. There is no initiative from the District Agricultural Office to protect these crops.

\section{Impacts of Floods}

Bihar is India's most flood-prone State and Gopalganj District is a flood-prone area. The Gandak River borders Paschim Champaran and Purba Champaran in the north. There is a danger of flood due to the breakage of the embankments on the Gandak River. There are two embankments, one just near the flow and another after some distance. Whenever there is breakage of the embankment, there is a flood in Gopalganj and some parts of Siwan and Chapara districts. A few years back the whole district was flooded because of the breakage of the embankment of the river Gandak near Bhaisahi village $(6-7 \mathrm{~km}$ in the east of Gopalganj town). During the rainy season when Gandak is full of water, the people of the nearby embankments live in fear of being washed away. The heavy security force is arranged by the district administration to protect the embankments from the breakage and from the miscreants and anti-social elements (local goons). The police-force patrols the embankments the whole night. They arrange lights on the banks of the river the whole night so that miscreants do not break up clods of mud to break the Bandh (embankment).

Even though there is the recurrent threat of flood devastation in the area, there are enormous reports of mismanagement and corruption regarding up-keeping up of the embankment. The villagers of the affected area and those settled near the Gandak Bandh (Diyara Area) reported that some contractors and their goons managed to make a hole in the Bandh, which resulted in the breakage of the Bandh and the whole south area of the district was flooded. They used to do this intentionally so that they could get the contract of repairing of the Bandh, where they could earn a large sum of money from the government fund in the flood control. At the same time, the local officials - (Block Development Officers) BDOs and others benefited from the flood rehabilitation work. Many BDOs and Circle Officers (COs) have been suspended several times due to their involvement in corruption during flood relief. One of the causes of the flood is silting of the bed of small rivers and choked drainage system in the area. There is Small River Gandaki, which is the only source of draining the rainwater from Gopalganj, stretching till Sonepur, and ending in the Gandak River. All the chanwara (deep bedded land where water logs during the rainy season and is useful for paddy) are connected to the Gandaki River to drain their water by making small channels (khadhi) so that extra water during heavy rains could be drained. However, over the years, the bed of Gandaki River has been filled up with silt. Earlier this river was 3-4 meters deep, now it is reduced to only $1-11 / 2$ meters. Earlier there was a steady flow of water as the bed was clear and deep, but now it is filled up and blocked by several obstacles and not able to drain the water completely, which causes floods during the heavy rain. The adjoining villages which are near the chanwara, and those which are in low-level areas get flooded because the river is not able to drain out the rainwater, it takes many days to clear due to heavy obstruction in the flow of current.

Again, another reason for the flood is the obstruction in the flow by constructing small bamboo bridges over the river (for commuting by the local villagers) by filling up more than $80 \%$ of its width by both ends inside the river. Due to this, a river having a width of the 100 meters could flow within 20 meters of clearance beneath the bamboo bridge. At some places, the river width has been narrowed down (river width ranging between 10 - 
5 meters), by the construction of the local bridges. There are hundreds of such bridges across the river - right from where it originates to where it ends. The number could be more, 100 is just the estimation for one district territory of Gopalganj, but this river flows across Siwan and Chapara districts as well, which is a long distance.

Local villagers are forced to construct such bridges because the government has failed to construct the bridges over the river, wherever they are required. They have to face many problems during the rainy season to go to the other villages and make daily purchases from the markets on another side of the river. They are continuously making demands to the local leaders (MLAs and MPs), for the construction of bridges over the river, but no one listens to their voices. Hence, with their own initiative and by collecting 'chanda' (donation), wood, bamboos, bricks, etc., they themselves put in their own labour and make the temporary, ordinary bridges to maintain their link across the river during the rainy season, but such bridges without any engineering skills, lessen the width of the river. There are many villagers whose relatives are on the other side of the river. In some cases, their agricultural lands are on one side of the river, but their houses are on the other side. As such, they have to cross the river every day.

The villagers reported that some 25-30 years ago the river bed was about to be excavated by the government. The government overseers had taken the measurement of the river for that purpose. Even some portion of the river under Siwan District was excavated; however, the work was not completed under Gopalganj District.

\section{Expectations of the People}

Regarding all the above-mentioned issues and problems, the people of Gopalganj were of the opinion that the government should give them subsidised pump sets, threshers, tractors, fertilizers, seeds, etc. The government should appoint some officers to check their crops, plants and trees from time to time so that they could be saved from the damage. Cooperative societies, which were providing them fertilizers and seeds earlier, are now totally defunct. Today, whatever agricultural support is provided by the government, only a few people - those who are powerful and have a good rapport with government officials, avail all the facilities and this does not reach the really needy.

For the protection of their crops from wild animals, they wanted that the government should take some action. They were planning to launch a dharna before the local administration in this regard. They were ready to gherao the district officers for not taking any steps so far for protecting their crops/shisham trees, providing flood management measures, excavating the river bed/correcting the water flow, constructing proper bridges over the river, etc.

\section{CONCLUSIONS AND RECOMMENDATIONS}

It could be concluded that farmers' perception regarding agriculture and food production is negative. Due to the shortage of labour due to rural-urban migration, the cultivation has become difficult. Even home labour force is also migrated or those stays at home do not want to do cultivation. The cost of production is very high and productivity is in negative. Due to the sharecropping system, the gross production on land has gone down. Many landed people are not letting out their lands on sharecropping and leaving cultivation as they have some other source of income through their sons and grandsons who had migrated to the urban centres. Those who had not any other source of income than cultivation they are bound to do cultivation even after there is negative productivity. The main source of irrigation is the private tube wells which are very costly. Other sources of irrigation such as canals, rivers, ponds etc are not useful for all. If electric tube wells would be provided to the villagers it would be much cheaper. Floods and 
wild animals are the main destroyers of the crops. Impact of climate change has resulted in the extinction of some important trees and important pulses from the area. The fertility of the land is diminishing day by day because of the regular use of chemical fertilisers. As the animal husbandry has almost diminished in the area so the manure is not available to the lands. Because of the high cost of keeping animals and change in local culture and behaviour of the younger generation keeping the animals is becoming difficult. For ploughing the land tractors are used so there is no need for keeping oxen. So agriculture and food production at the local level is going down.

Farmers should be motivated to keep cultivation, keep animals, and continue agriculture in the area by giving some incentives in terms subsidy on agricultural tools, fertilizers, seeds, diesel, and by guiding them about the new ways of agriculture and adaptation with the climate change by appointing some local agricultural officers. Some measures should be applied to protect their crops from the floods and forest animals.

\section{REFERENCES:}

Alam G. M. M., Alam K. M. S. (2017): Climate change perceptions and local adaptation strategies of hazard-prone rural households in Bangladesh. Climate Risk Management 17 (2017) 52-63, journal homepage: www.elsevier.com/ locate/crm (16.09.2019).

Banerjee R. R. (2014): Farmers' perception of climate change, impact and adaptation strategies: a case study of four villages in the semi-arid regions of India. Natural Hazards, Journal of the International Society for the Prevention and Mitigation of Natural Hazards; Springer, ISSN 0921-030X. Nat Hazards DOI 10.1007/s11069-014-1466-z. https://link.springer.com/article/10.1007/ s11069-014-1466-z (16.09.2019).

Dales J. (2014 Oct 28): Study: Different Perceptions of Agriculture. Farms.com https://www.farms.com/ag-industrynews/study-farmers-and-consumers-differin-their-perceptions-of-agriculture-300.aspx (31.12.2020).

Hegde N. G. (2010 Sept 2010): Small Holders and Role of NGOs in Improving their Livelihood. Paper presented at the NAARM workshop, Hyderabad.

Kelkar U., Narula K. K., Sharma V. P., \& Chandna U. (2008): Vulnerability and adaptation to climate variability and water stress in Uttarakhand State, India. Glob Environ Change 18:564-574. https://doi.org/10.1016/j.gloenvcha.2008.0 9.003 (06.09.2019).

Mcharo, A. C. (2013): Perception of farmers on effectiveness of agricultural extension agents in knowledge transfer to maize growers in Kilindi district a dissertation submitted in partial fulfilment of the requirements for the degree of Master of Arts in rural development for Sokoine university of agriculture. Morogoro, Tanzania. https:/ / link.springer.com/article/10.1007/ s10668-008-9168-x (06.09.2019).

Meena G. L. and Punjabi N. K. (2012): Farmer's perception towards agriculture technology in tribal region of Rajasthan. Raj. J. Extn. Edu. 20: 92-96. http://www.rseeudaipur.org/wpcontent/uploads/2013/02/233.pdf (16.09.2019).

Praveen D. and Ramachandran A. (2015): Farmers' perceptions of climate change and the proposed agriculture adaptation strategies in a semi arid region of South India. Journal of Integrative Environmental Sciences.

DOI: 10.1080/1943815X.2015.1062031.

Ravi S., Ropan B., Sarju P., Gopal K. A. and Chandresh D. (2015): Constraints perceived by farmers in crop-dairy mixed farming system on small farms in Parbhani district of 
I J R B A T, Issue (IX), Vol. II, May 2021: 74-

A Double-Blind Peer Reviewed \& Refereed Journal

Marathwada region (Maharashtra), India. Plant Archives, Vol. 15, No.1; pp. 41-46. http:/ / plantarchives.org/PDF\%2015\%20\%201/41-46\%20(2824).pdf (16.09.2019).

Udmale P., Ichikawa Y., Manandhar S., Ishidaira H. and Kiem A. S. (2014): Farmers' perception of drought impacts, local adaptation and
e-ISSN $2347-517 X$

Original Article

administrative mitigation measures in Maharashtra State, India. International Journal of Disaster Risk Reduction 10, 250269. www.elsevier.com/locate/ijdrr (06.09.2019).

International Conference on Smart and Sustainable City and Big Data (ICSSC) 